\title{
MEKANISME TATA KELOLA KORPORASI SEBAGAI PEREDUKSI PRAKTIK PEREKAYASAAN LABA
}

\author{
Alwan Sri Kustono ${ }^{1}$ \\ Email:alwankustono@yahoo.com
}

\begin{abstract}
Management can choose accounting policies for expected earnings reporting. This study purpose to examineeffect of corporate governance mechanism managerial ownership, such as audit committees, board size, composition of independent commissioners, board size, and firm size. The sample used is manufacturing companies listed on the Indonesia Stock Exchange (IDX) during the period 2014-2015. Institutional investors, managerial ownership, audit committees, have a positive coefficient. This shows that the independent variable has a positive influence on earnings management that means earnings management changes in the direction of changes in the independent variables. The proportion of independent commissioners, board size, firm size has a negative coefficient. This shows that these independent variables has a negative influence on earnings management which means earnings management changes direction with changes in the independent variable.
\end{abstract}

Keywords: Institutional investors, managerial ownership, audit committees, independent commissioners, board size, firm size, earnings management

\section{PENDAHULUAN}

\subsection{Latar Belakang}

Laporan keuangan seharusnya mengindikasikan situasi perusahaan secara nyata, karena pada akhirnya laporan keuangan akan dijadikan pedoman pengambilan keputusan oleh berbagai pihak pengguna informasi keuangan tersebut, yaitu pihak dari dalam maupun pihak luar. Kinerja perusahaan sering diukur dengan menggunakan angka-angka laba. Informasi laba sebagai bagian dari laporan keuangan, sering menjadi target rekayasa melalui tindakan manajemen. Hal ini terkait dengan adanya perbedaan kepentingan antara pihak pemegang saham dan kreditor sebagai prinsipal sedangkan manajer sebagai agen.

\footnotetext{
${ }^{1}$ Corresponding author: Jurusan Akuntansi, Fakultas Ekonomi dan Bisnis, Universitas Jember, Jalan Kalimantan No. 37, Kampus Tegalboto, Kecamatan Sumbersari, Jember, 68121, Jawa Timur, Indonesia.
} 
Manajemen dapat memilih kebijakan akuntansi tertentu untuk melaporkan laba ekspektasian. Dengan melaporkan laba yang telah dimanipulasi, manajer dapat mempengaruhi transfer kesejahteraan dari pemegang saham kepada dirinya.

Terbongkarnya skandal-skandal manipulasi akuntansi sempat membuat resah dunia bisnis internasional. Ironinya, manipulasi akuntansi justru dilakukan oleh pihak dari dalam yang dipercaya mengelola sumber daya perusahaan oleh pemilik. Ditambah lagi dengan adanya krisis global yang terjadi, tepatnya dimulai dari tahun 2008, yang tentunya sangat memiliki pengaruh terhadap keuangan setiap negara, tidak terkecuali Indonesia. Para manajer perusahaan terbuka berpikir keras dan berupaya menjaga kestabilan nilai perusahaan.

Keresahan pelaku bisnis mulai menimbulkan upaya perlindungan yang tidak hanya ditujukan kepada pihak dari dalam tetapi juga bagi pihak luar yang sering dijadikan target asimetri informasi. Tata kelola perusahaan kemudian merebak menjadi isu sentral yang diperbincangkan dunia sebagai jawaban dari masalah keagenan. Tata kelola perusahaan atau tata kelola korporasi diyakini para peneliti memiliki andil besar dalam menjaga integritas laporan keuangan dari praktik perekayasaan laba.

Penelitian terdahulu meneliti mengenai variabel-variabel tata kelola korporasi yang memiliki pengaruh terhadap perekayasaan laba (Aygun et al. 2014; Hashim 2012; Moh Fadzilah 2017; Rossi 2014). Peneliti yang lain meneliti pengaruh perekayasaan laba terhadap nilai pasara perusahaan (Lestari dan Pamudji 2013; Ustman et al. 2016). Penelitian tersebut menunjukkan variabel besaran korporasi yang mempunyai pengaruh terhadap variabel perekayaan laba. Usman et al. (2016) menyatakan bahwa perekayasaan laba berpengaruh terhadap citra perusahaan di pasar.

Berbeda dengan penelitian terdahulu, mekanisme tata kelola korporasi dalam penelitian ini mencakup investor institusi, managerial ownership, komite audit, besaran dewan komisaris, persentase komisaris independen, besaran dewan komisaris, dan besaran korporasi. Alasan pemilihan mekanisme tata kelola korporasi tersebut adalah yang pertama, tata kelola korporasi merupakan suatu perangkat yang ideal yang didalamnya terkandung tata kelola perusahaan yang baik termasuk kode etik yang dijalankan perusahaan dalam berbisnis, sehingga akan sangat bermanfaat apabila diterapkan dengan baik.

Berdasarkan latar belakang masalah yang telah diuraikan sebelumnya, maka pokok permasalahan yang ada dalam penelitian ini adalah apakah mekanisme tata kelola korporasi yang terdiri dari Investor institusi, managerial ownership, komite audit, besaran dewan komisaris, persentase komisaris independen, besaran dewan komisaris, dan besaran korporasi memiliki pengaruh terhadap praktik perekayasaan laba pada perusahaan manufaktur terbuka di Indonesia pada periode 2014 sampai dengan 2015.

\section{TINJAUAN PUSTAKA}

\subsection{Perekayasaan laba}

Sering kali manajer dihadapkan pada pengukuran kinerja yang berbasis angkaangka akuntansi. Salah satu ukuran yang umum digunakan adalah laba. Manajer yang gagal mencapai target laba dianggap sebagai manajer yang buruk. Dampak negatif yang timbul adalah pemotongan bonus atau pemecatan. Lebih parah lagi manajer yang dianggap gagal, reputasinya di pasar tenaga kerja akan turun. Penelitian Frudenberg dan Tirole memberikan bukti terhadap kasus tersebut (Fudenberg dan Tirole 1995). 
Maka dari itu, manajer akan lebih menyukai melakukan perekayasaan laba untuk mengurangi risiko yang tidak tersiversifikasi dan peningkatan sumber dayanya.

Perekayasaan laba merupakan tindakan mempercantik laporan keuangan yang dilakukan oleh manajer (Rossi 2014). Perekayasaan laba terjadi ketika manajer menggunakan pertimbangan dalam pelaporan keuangan dan dalam penyusunan transaksi untuk mengubah pelaporan keuangan agar dapat memberikan gambaran yang bagus mengenai kinerja ekonomi perusahaan pada stockholders ataupun agar dapat mempengaruhi hasil kontrak yang bergantung pada angka-angka akuntansi yang dilaporkan.

Dengan demikian, perekayasaan laba dapat didefinisikan sebagai intervensi yang sengaja dilakukan oleh manajemen dalam proses penetapan laba, biasanya untuk mencapai tujuan atau keinginan individu. Perekayasaan laba yang merupakan tindakan campur tangan manajemen dalam proses penyusunan laporan keuangan untuk mengubah pelaporan laba dalam laporan keuangan tentu saja di satu pihak menguntungkan manajemen atau perusahaan, namun dipihak lain merugikan pihakpihak yang menggunakan informasi dalam laporan keuangan tersebut karena esensi didalamnya tidak mencerminkan kondisi perusahaan yang sesungguhnya.

\subsection{Mekanisme Tata Kelola Korporasi}

Tata kelola korporasi adalah cara bagaimana pemilik modal dan penyedia dana melakukan pengawasan pada kegiatan operasional perusahaan. Tujuan pengawasan tersebut adalah memastikan bahwa tujuan perusahaan menjadi prioritas utama. Mekanisme tersebut dapat dalam bentuk penetapan alat kelengkapan perusahaan atau mekanisme dari luat. Mekanisme dari dalam, dapat berupa pembentukan dewan komisaris, managerial ownership, dan kompensasi eksekutif. Mekanisme yang dari luar dpat berupa pengawasan pasar, Investor institusi, dan konvenan utang. Mekanisme tata kelola korporasi adalah dewan komisaris dan komisaris, komite audit, kualitas audit, dan Investor institusi (Mohd Fadzilah, 2017).

\subsection{Pengaruh Investor Institusi terhadap Praktik Perekayasaan Laba}

Investor institusi merupakan bentuk kepemilikan dalam jumlah tertentu yang dimiliki oleh institusi. Besaran saham yang dimiliki memberikan kemampuan bagi investor tersebut untuk mengontrol keputusan operasional perusahaan. Selain jumlah, investor institusi juga didukung dengan kompetensi yang mumpuni sehingga pengawasannya lebih efektif.

Keberadaan investor institusi dapat memotivasi manajer untuk lebih mengutamakan kepentingan perusahaan (Shaiks et al. 2012). Manajer akan menurunkan niata untuk melakukan tindakan yang menguntungkan dirinya.

Keberadaan investor institusi mejadi salah satu alasan menurunnya dorongan manajer memntingkan dirinya. Pengawasan yang intensif dari investor ini menekan kecenderungan oportunistik manajemen (Susanto 2018). Rumusan hipotesis dalam penelitian ini adalah sebagai berikut:

H1 : Investor institusi memiliki pengaruh terhadap praktik perekayasaan laba.

\subsection{Pengaruh Managerial Ownership terhadap Praktik Perekayasaan Laba}

Salah satu mekanisme tata kelola korporasi lainnya adalah hak manajer untuk memiliki perusahaan. Dengan kata lain, manajer menjadi sebagian investor di 
perusahaan yang dikelola. Persentase jumlah saham yang dimiliki oleh manajemen dari seluruh modal saham perusahaan dikenal dengan managerial ownership.

Manajer yang bertidak sebagai investor diduga meneurunkan insentifnya untuk melakukan tindakan oportunistik. Semakin besar saham yang dimiliki akan menyelaraskan dengan kepentingan pemegang saham lainnya (Aygun et al. 2014). Dengan kata lain, manajemen yang memiliki saham besar cenderung tidak melakukan perekayasaan laba karena adanya keselarasan tujuan manajer dengan pemegang saham (Azeem et al. 2013). Rumusan hipotesis dalam penelitian ini adalah sebagai berikut:

H2 : Managerial ownership memiliki pengaruh terhadap praktik perekayasaan laba.

\subsection{Pengaruh Komite Audit terhadap Praktik Perekayasaan Laba}

Peran komite audit mempunyai peran yang sangat penting dan strategis dalam hal memelihara kredibilitas proses penyusunan laporan keuangan seperti halnya menjaga terciptanya sistem pengawasan perusahaan yang memadai serta dilaksanakannya tata kelola perusahaan yang baik. Dengan berjalannya fungsi komite audit secara efektif, maka control terhadap perusahaan akan lebih baik sehingga, konflik keagenan yang terjadi akibat keinginan manajemen untuk meningkatkan kesejahteraannya sendiri dapat diminimalisasi (Dar et al. 2011).

Dar et. al (2011) meneliti pengaruh tata kelola korporasi dan komite audit, dengan mengevaluasi dan melakukan sintesa beberapa penelitian terdahulu tentang tata kelola korporasi yang berkaitan dengan komite audit. Penelitian ini melaporkan bahwa bukti menunjukkan hubungan positif antara eksistensi komite audit dengan kualitas laporan keuangan dan kinerja perusahaan. Rumusan hipotesis dalam penelitian ini adalah sebagai berikut:

H3 : Komite audit memiliki pengaruh terhadap praktik perekayasaan laba.

\subsection{Pengaruh Persentase Komisaris Independen terhadap Praktik Perekayasaan Laba}

Komposisi dewan komisaris merupakan salah satu karakteristik dewan yang berhubungan dengan kandungan informasi laba. Melalui perannya dalam menjalankan fungsi pengawasan, komposisi dewan dapat mempengaruhi pihak manajemen dalam menyusun laporan keuangan sehingga dapat diperoleh suatu laporan laba yang berkualitas Komposisi dewan komisaris di perusahaan dapat mempengaruhi kualitas laba yang dilaporkan (Lestari dan Pamudji 2013; Mansor et al. 2013; Young 2015).

Masuknya dewan yang berasal dari luar perusahaan meningkatkan efektivitas dewan tersebut dalam mengawasi manajemen untuk mencegah kecurangan laporan keuangan. Hasil penelitiannya juga melaporkan bahwa komposisi dewan komisaris lebih penting untuk mengurangi terjadinya kecurangan pelaporan keuangan, daripada kehadiran komite audit.

Indikator yang digunakan untuk mengukur persentase komisaris independen adalah persentase jumlah anggota dewan yang berasal dari luar perusahaan, dari seluruh jumlah anggota dewan komisaris perusahaan (Lestari dan Pamudji 2013).

Rumusan hipotesis dalam penelitian ini adalah sebagai berikut:

H4 : Persentase komisaris independen memiliki pengaruh terhadap praktik perekayasaan laba. 


\subsection{Pengaruh Besaran Dewan Komisaris terhadap Praktik Perekayasaan Laba}

Komisaris sebagai organ perusahaan bertugas dan bertanggung jawab secara kolegial dalam pengawasan perusahaan. Masing-masing anggota Komisaris dapat melaksanakan tugas dan mengambil keputusan sesuai dengan pembagian tugas dan wewenangnya. Namun, pelaksanaan tugas oleh masing-masing anggota Komisaris tetap merupakan tanggung jawab bersama.

Terdapat beberapa hasil penelitian empiris yang telah membuktikan adanya hubungan antara peran pengawasan oleh dewan komisaris dengan adanya praktik perekayasaan laba. Hubungan dewan komisaris dengan kemungkinan dilakukannya perekayasaan laba merupakan suatu hal yang penting untuk diperhatikan dalam disiplin akuntansi (Rossi 2014).

Besaran dewan komisaris sebagai mekanisme tata kelola korporasi mempunyai pengaruh terhadap perekayasaan laba (Essa et al. 2016; Al-Shetwi 2011; Omrani 2016). Rumusan hipotesis dalam penelitian ini adalah sebagai berikut:

H5 : Besaran dewan komisaris memiliki pengaruh terhadap praktik perekayasaan laba.

\subsection{Pengaruh Besaran Korporasi terhadap Praktik Perekayasaan Laba}

Teori akuntansi positif mengasumsi perusahaan yang lebih dekat dengan munculnya biaya politik mempunyai insentif untuk melakukan perekayasaan laba. Semakin besar suatu perusahaan cenderung lebih sensitif dengan biaya politik. Perusahaan-perusahaan besar merupakan subyek yang menjadi perhatian publik dibandingkan dengan perusahan-perusahaan yang lebih kecil. Fluktuasi laba perusahaan yang besar lebih menarik perhatian pemangku kepentingan (Kustono dan Effendi 2017).

Besaran korporasi seringkali menjadi sorotan masyarakat dalam menilai besar kecilnya suatu perusahaan. Penelitian terdahulu menunjukkan besaran korporasi memiliki pengaruh terhadap perekayasaan laba (Muklis 2016; Titik dan Putri 2014). Perusahaan yang lebih besar berkesempatan lebih kecil dalam memanipulasi laba dibandingkan perusahaan kecil. Rumusan hipotesis dalam penelitian ini adalah sebagai berikut:

H6 : Besaran korporasi memiliki pengaruh terhadap praktik perekayasaan laba.

\section{METODE PENELITIAN}

Penelitian ini merupakan penelitian studi empiris dalam bentuk explanatory research atau penelitian pengujian hipotesis. Metode penelitian yang digunakan adalah kausalitas yaitu untuk menguji pengaruh dari variabel independen terhadap variabel dependen. Variabel independen terdiri dari mekanisme tata kelola korporasi yang diukur dengan Investor institusi, managerial ownership, komite audit, besaran dewan komisaris, persentase komisaris independen, besaran dewan komisaris, dan besaran korporasi. Variabel dependen dalam penelitian ini adalah praktik perekayasaan laba.

\subsection{Jenis dan Sumber Data}

Jenis penelitian yang dilakukan adalah penelitian empiris. Sumber data yang digunakan dalam penelitian ini adalah data sekunder yang diperoleh dari laporan keuangan tahunan perusahaan manufaktur yang listed dalam Bursa efek Indonesia (BEI) selama periode 2014 sampai 2015. Data sekunder yang digunakan meliputi 
laporan posisi keuangan, Laporan Laba Rugi Komprehensif, dan Catatan Atas Laporan Keuangan yang diperoleh dari Indonesian Capital Market Directory tahun 2014 - 2015.

\subsection{Populasi dan Sampel Penelitian}

Populasi penelitian ini adalah seluruh perusahaan manufaktur terbuka di Indonesia (BEI). Periode pengamatan penelitian dilakukan dari tahun 2014 sampai dengan tahun 2015. Alasan pemilihan perusahaan manufaktur dalam penelitian ini adalah karena perusahaan manufaktur merupakan perusahaan dengan jumlah yang besar serta memiliki tingkat sensitivitas yang tinggi terhadap setiap kejadian baik intern maupun ekstern perusahaan, sehingga menarik untuk diteliti.

Sampel yang digunakan adalah perusahaan manufaktur yang terdaftar di Bursa Efek Indonesia (BEI) selama periode tahun 2014-2015. Pemilihan sampel berdasarkan metode purposive sampling yaitu sampel yang dipilih dengan cermat sehingga relevan dengan rancangan penelitian atau pemilihan sampel secara acak mempunyai tujuan atau target tertentu. Sampel diambil dengan kriteria sebagai berikut:

1. Terdaftar sebagai perusahaan manufaktur di Bursa Efek Indonesia (BEI) yang tercatat pada tahun 2014-2015.

2. Perusahaan menerbitkan laporan keuangan untuk periode yang berakhir 31 Desember selama periode penelitian 2014-2015.

3. Perusahaan tidak mengalami transaksi merger, akuisi, dan perubahan kelompok usaha (restrukturisasi)

4. Telah membentuk Komisaris independen sesuai peraturan yang berlaku.

5. Memiliki data mengenai kepemilikan institusi, managerial ownership, komite audit, dan komisaris independen.

Data diperoleh dari catatan laporan keuangan perusahaan manufaktur yang terdaftar di BEI, serta data dari Bursa Efek Indonesia yang dapat didownload dari website Indonesia Stock Exchange.

\section{HASIL DAN PEMBAHASAN}

\subsection{Statistik Deskriptif Penelitian}

Statistik deskriptif merupakan proses transformasi data penelitian dalam bentuk tabulasi sehingga mudah dipahami dan diinterprestasikan. Tujuannya adalah untuk mengetahui gambaran umum mengenai data penelitian tersebut dan hubungan antara variabel yang akan digunakan dalam penelitian. Statistik deskriptif digunakan untuk mengetahui mean, maksimum, minimum, dan standar deviasi dari setiap variabel sampel yang diteliti. Hasil perhitungan statistik deskriptif sebagai berikut :

Tabel 1. Statistik Deskriptif

\begin{tabular}{lrrrr}
\hline & Minimum & Maximum & \multicolumn{1}{c}{ Mean } & Std. Deviation \\
\hline X1 & 12,07 & 99.92 & 71.2132 & 19.31609 \\
X2 & .00 & 70.00 & 4.7480 & 9.99028 \\
X3 & .00 & 1.00 & .4392 & .49797 \\
X4 & 11.11 & 100.00 & 40.9051 & 13.23704 \\
X5 & 2.00 & 11.00 & 4.5878 & 1.85138 \\
X6 & 26,169 & 40,382 & 34,429 & 5.587 \\
\hline
\end{tabular}

Sumber Data: Hasil Pengolahan SPSS 
Tabel 1 menyajikan statistik deskriptif data sampel perusahaan selama tahun 2014-2015. Dari tabel tersebut dapat diketahui nilai minimum, nilai maksimum, nilai rata-rata, dan standar deviasi untuk masing-masing variabel baik variabel dependen maupun variabel independen.

\subsection{Pengujian Hipotesis}

\subsubsection{Analisis Regresi Berganda}

Besarnya pengaruh variabel independen terhadap variabel dependen diuji dengan menggunakan persamaan regresi berganda (multiple regression). Variabel dependen dalam penelitian ini adalah perekayasaan laba (Y), sedangkan variabel independennya adalah Investor institusi (X1), managerial ownership (X2), komite audit (X3), besaran dewam komisaris (X4), persentase komisaris independen (X5), besaran dewan komisaris (X6), besaran korporasi (X7). Dari pengolahan data yang telah dilakukan diperoleh hasil sebagai berikut:

Tabel 2. Hasil Regresi

\begin{tabular}{lcrrrr}
\hline \multirow{2}{*}{ Model } & \multicolumn{2}{c}{$\begin{array}{c}\text { Unstandardized } \\
\text { Coefficients }\end{array}$} & $\begin{array}{c}\text { Standardized } \\
\text { Coefficients }\end{array}$ & t & \multirow{2}{*}{ Sig. } \\
\cline { 2 - 4 } & \multicolumn{1}{c}{ B } & \multicolumn{1}{c}{ Std. Error } & \multicolumn{1}{c}{ Beta } & & \\
\hline (Constant) & 0,370 & 0,220 & & 1,678 & 0,096 \\
X1 & 0,006 & 0,002 & 0,238 & 3,154 & 0,002 \\
X2 & 0,010 & 0,004 & 0,204 & 2,605 & 0,010 \\
X3 & 0,164 & 0,074 & 0,170 & 2,229 & 0,027 \\
X4 & $-0,005$ & 0,003 & $-0,148$ & $-2,010$ & 0,046 \\
X5 & $-0,045$ & 0,022 & $-0,175$ & $-2,111$ & 0,037 \\
X6 & $-1,9 E-014$ & 0,000 & $-0,220$ & $-2,535$ & 0,012 \\
\hline \multicolumn{2}{c}{ Sumber Data: Hasil Pengolahan SPSS }
\end{tabular}

Berdasarkan tabel 2 dapat diketahui konstanta dan koefisien regresi masingmasing variabel yang diteliti. Investor institusi, managerial ownership, komite audit, memiliki koefisien yang positif, yaitu masing-masing 0,006 untuk variabel Investor institusi, 0,010 untuk variabel managerial ownership, 0,164 dan untuk variabel komite audit, 0,047. Hal ini menunjukkan bahwa ketiga variabel independen memiliki pengaruh positif terhadap perekayasaan laba yang berarti bahwa perekayasaan laba berubah searah dengan perubahan variabel independennya.

Persentase komisaris independen, besaran dewan komisaris, besaran korporasi memiliki koefisien yang negatif, yaitu masing-masing -0.005 untuk variabel persentase komisaris independen, -0.045 untuk variabel besaran dewan komisaris, 1,9E-0,14 untuk variabel besaran korporasi. Hal ini menunjukkan bahwa ketiga variabel independen tersebut memiliki pengaruh negatif terhadap perekayasaan laba yang berarti bahwa perekayasaan laba akan berubah berlawanan arah dengan perubahan variabel independennya. Dari analisis regresi yang telah dilakukan juga diperoleh R2 sebesar 0,282. Hal ini menunjukkan bahwa terdapat pengaruh antara variabel independen (investor institusi, managerial ownership, komite audit, besaran dewan komisaris, persentase dewan komisaris, besaran dewan komisaris, besaran korporasi) terhadap variabel dependen (perekayasaan laba) sebesar 28,2\%, sedangkan sisanya sebesar $71,8 \%$ dipengaruhi oleh variabel lain selain variabel independen yang digunakan dalam penelitian ini, misalnya: faktor politik, ekonomi, sosial, dll. 


\subsubsection{Pengujian Hipotesis}

Untuk mengetahui apakah secara individu masing-masing variabel independen memiliki pengaruh atau tidak, dilihat dari nilai t hitung yang dibandingkan dengan nilai $\mathrm{t}$ tabel pada taraf signifikan 5\% $(\alpha=5)$. Apabila tingkat signifikansinya lebih kecil daripada $\alpha$ maka $\mathrm{H} 0$ ditolak, yang berarti secara variabel independen memiliki pengaruh terhadap variabel dependen, dan sebaliknya apabila tingkat signifikansinya lebih besar daripada $\alpha$ maka $\mathrm{H} 0$ diterima, yang berarti secara variabel independen tidak memiliki pengaruh terhadap variabel dependen.

Berdasarkan tabel 2 diatas, pengujian masing-masing variabel dapat dijelaskan sebagai berikut:

a. Variabel investor institusi memiliki nilai tingkat signifikasi sebesar 0,002 dengan t hitung sebesar 3,154. Nilai signifikansi tersebut lebih kecil dari $\alpha=0,05$, maka $\mathrm{H} 0$ ditolak yang berarti bahwa secara variabel investor institusi memiliki pengaruh positif terhadap variabel praktik perekayasaan laba.

b. Variabel managerial ownership memiliki nilai tingkat signifikasi sebesar 0,010 dengan thitung sebesar 2,605. Nilai signifikansi tersebut lebih kecil dari $\alpha=0,05$, maka H0 ditolak yang berarti bahwa secara variabel managerial ownership memiliki pengaruh positif terhadap variabel praktik perekayasaan laba.

c. Variabel komite audit memiliki nilai tingkat signifikasi sebesar 0,027dengan $\mathrm{t}$ hitung sebesar 2,229. Nilai signifikansi tersebut lebih kecil dari $\alpha=0,05$, maka $\mathrm{H} 0$ ditolak yang berarti bahwa variabel keberadaan komite audit memiliki pengaruh positif terhadap variabel praktik perekayasaan laba.

d. Variabel persentase komisaris independen memiliki nilai tingkat signifikasi sebesar 0,046 dengan $\mathrm{t}$ hitung sebesar -2,010. Nilai signifikansi tersebut tersebut lebih kecil dari $\alpha=0,05$, maka $\mathrm{H} 0$ ditolak yang berarti bahwa secara variabel persentase komisaris independen memiliki pengaruh negatif terhadap variabel praktik perekayasaan laba.

e. Variabel besaran dewan komisaris memiliki nilai tingkat signifikasi sebesar 0,037 dengan t hitung sebesar -2,111. Nilai signifikansi tersebut tersebut lebih kecil dari $\alpha=0,05$, maka H0 ditolak yang berarti bahwa secara variabel besaran dewan komisaris memiliki pengaruh negatif terhadap variabel praktik perekayasaan laba.

f. Variabel besaran korporasi memiliki nilai tingkat signifikasi sebesar 0,012 dengan t hitung sebesar $-2,535$. Nilai signifikansi tersebut lebih kecil dari $\alpha=0,05$, maka H0 ditolak yang berarti bahwa secara variabel besaran korporasi memiliki pengaruh negatif terhadap variabel praktik perekayasaan laba.

\subsection{Pembahasan}

\subsubsection{Pengaruh Investor Institusi terhadap Praktik Perekayasaan Laba}

Variabel investor institusi mempunyai nilai signifikansi 0,002, yang berarti nilai ini lebih kecil dari taraf signifikansi sebesar 0,05 seperti yang diharapkan peneliti, sehingga pengujian menunjukkan hasil bahwa hipotesis pertama diterima. Dengan demikian variabel Investor institusi menunjukkan hubungan yang positif memiliki pengaruh terhadap praktik perekayasaan laba. Hal ini menunjukkan bahwa adanya Investor institusi yang bertindak sebagai pihak yang memonitor perusahaan dapat mempengaruhi pihak manajerial dalam melakukan pelaporan keuangan. Investor institusi memiliki kemampuan untuk mengendalikan pihak manajemen melalui proses monitoring secara efektif sehingga mengurangi tindakan manajemen melakukan manipulasi keuangan. 
Hasil penelitian ini konsisten dengan Omrani (2016) yang menunjukkan hasil bahwa investor institusi memiliki pengaruh terhadap perekayasaan laba (Omrani, 2016). Tindakan pengawasan perusahaan oleh pihak pemegang saham institusional dapat mendorong manajer untuk lebih memfokuskan perhatiannya terhadap kinerja perusahaan sehingga akan mengurangi perilaku opportunistik atau mementingkan diri sendiri. Hasil penelitian ini memberikan simpulan investor institusi dapat menekan kecenderungan manajemen untuk memanfaatkan diskresionari dalam laporan keuangan sehingga memberikan kualitas laba yang dilaporkan.

\subsubsection{Pengaruh Managerial Ownership terhadap Praktik Perekayasaan Laba}

Variabel managerial ownership mempunyai nilai signifikansi 0,010, yang berarti nilai ini lebih kecil dari taraf signifikansi sebesar 0,05 seperti yang diharapkan peneliti, sehingga pengujian menunjukkan hasil bahwa hipotesis kedua diterima. Dengan demikian variabel managerial ownership menunjukkan hubungan yang positif memiliki pengaruh terhadap praktik perekayasaan laba. Hal ini menunjukkan bahwa managerial ownership mampu menjadi mekanisme tata kelola korporasi yang dapat mengurangi ketidakselarasan kepentingan antara manajemen dengan pemilik/pemegang saham yang timbul dalam teori keagenan.

Hasil penelitian ini konsisten dengan penelitian yang menunjukkan hasil bahwa managerial ownership memiliki pengaruh pada perekayasaan laba (Aygun et al. 2014; Spinos 2013). Pemahaman terhadap managerial ownership sangat penting karena berkaitan dengan pengendalian operasional perusahaan. Kepemilikan seorang manajer akan ikut menentukan kebijakan dan pengambilan keputusan terhadap metode akuntansi yang diterapkan pada perusahaan yang mereka kelola. Secara umum dapat dikatakan bahwa persentase tertentu kepemilikan saham oleh pihak manajemen cenderung mempengaruhi tindakan manajemen untuk melakukan manipulasi keuangan yang akan mempengaruhi kualitas laba. Dengan kepemilikan tersebut, manajer akan merasakan langsung dampak dari setiap keputusannya termasuk dalam menentukan kebijakan perusahaan sehingga dapat menurunkan tindakan opportunistik.

\subsubsection{Pengaruh Komite Audit terhadap Praktik Perekayasaan laba}

Variabel komite audit mempunyai nilai signifikansi 0,027 , yang berarti nilai ini lebih kecil dari taraf signifikansi sebesar 0,05 seperti yang diharapkan peneliti, sehingga pengujian menunjukkan hasil bahwa hipotesis ketiga diterima. Dengan demikian variabel komite audit menunjukkan hubungan yang positif memiliki pengaruh terhadap praktik perekayasaan laba. Hal ini menunjukkan bahwa keberadaan komite audit menjadi sangat bermanfaat bagi perusahan dalam hal terwujudnya laporan keuangan yang berkualitas apabila tugas-tugas komite audit seperti yang telah ditetapkan dalam Kep-29/PM/2004 dilaksanakan dengan baik bukan sekedar pemenuhan regulasi.

Hasil penelitian ini konsisten dengan penelitian terdahulu yang menunjukkan hasil penelitian adanya pengaruh keberadaan komite audit terhadap perekayasaan laba (Dar et al., 2011; Mansor et al., 2013; Rossi, 2014). Dalam pelaksanaan tugasnya, komite audit dengan pengetahuan dan pengalaman yang berkaitan dengan perusahaan dan keuangannya, dapat membatasi ruang gerak manajemen dalam melakukan perekayasaan laba. Dengan berjalannya fungsi komite audit secara efektif, maka control terhadap perusahaan akan lebih baik sehingga konflik keagenan yang terjadi 
akibat keinginan manajemen untuk meningkatkan kesejahteraannya sendiri dapat diminimalisir. Hasil penelitian ini memberikan simpulan bahwa keberadaan komite audit dapat mengurangi aktivitas perekayasaan laba.

\subsubsection{Pengaruh Persentase Komisaris independen terhadap Praktik Perekayasaan laba}

Variabel persentase komisaris independen mempunyai nilai signifikansi 0,046, yang berarti nilai ini lebih kecil dari taraf signifikansi sebesar 0,05 seperti yang diharapkan peneliti, sehingga pengujian menunjukkan hasil bahwa hipotesis kelima diterima. Namun mempunyai nilai t hitung -2,010, yang berarti menunjukkan arah negatif. Dengan demikian variabel persentase komisaris independen menunjukkan hubungan yang negatif memiliki pengaruh terhadap praktik perekayasaan laba. Hal ini menunjukkan bahwa persentase komisaris independen tidak terbukti meningkatkan kualitas laporan keuangan dari praktek manipulasi keuangan.

Hal ini dapat dijelaskan, pertama, pengangkatan komisaris independen perusahaan mungkin hanya dilakukan untuk pemenuhan regulasi saja tapi tidak dimaksudkan untuk menegakkan Tata kelola korporasi di dalam perusahaan. Kedua, ketentuan minimum komisaris independen sebesar 30\% mungkin belum cukup tinggi untuk menyebabkan para komisaris independen tersebut dapat mendominasi kebijakan yang diambil oleh dewan komisaris. Jika komisaris independen merupakan pihak mayoritas (>50\%) maka mungkin dapat lebih efektif dalam menjalankan peran monitoring dalam perusahaan. Tetapi jika pengangkatannya belum dilandasi kebutuhan (needs) perusahaan tapi hanya sebatas pemenuhan regulasi, maka persentase komisaris independen mungkin tidak perlu diperbanyak, tetap sesuai peraturan yang ada (minimal 30\%).

\subsubsection{Pengaruh Besaran Dewan Komisaris terhadap Praktik Perekayasaan Laba}

Variabel besaran dewan komisaris mempunyai nilai signifikansi 0,037, yang berarti nilai ini lebih kecil dari taraf signifikansi sebesar 0,05 seperti yang diharapkan peneliti, sehingga pengujian menunjukkan hasil bahwa hipotesis keenam diterima. Namun mempunyai nilai t hitung $-2,111$, yang berarti menunjukkan arah negatif. Dengan demikian variabel besaran dewan komisaris menunjukkan hubungan yang negatif memiliki pengaruh terhadap praktik perekayasaan laba.

Hasil ini konsisten dengan penelitian yang menunjukkan hasil penelitian adanya korelasi negatif antara besaran dewan komisaris terhadap perekayasaan laba (Rossi, 2014). Dewan komisaris ternyata belum mampu menjadi mekanisme Tata kelola korporasi yang dapat menurunkan tingkat manipulasi keuangan, mengingat dewan komisaris syarat akan konflik keagenan. Hal ini dikarenakan bahwa keinginan pemilik perusahaan dan para pihak yang berkepentingan lainnya (stakeholders) tidak selaras dengan dewan komisaris.

Dewan komisaris perusahaan dengan kemungkinan kecurangan laporan keuangan dan menemukan adanya hubungan negatif antara persentase anggota noneksekutif dalam dewan komisaris dan kemungkinan kecurangan, dengan membandingkan antara perusahaan yang melakukan kecurangan dengan perusahaan yang tidak melakukan kecurangan. 


\subsubsection{Pengaruh Besaran Korporasi terhadap Praktik Perekayasaan Laba}

Variabel besaran korporasi mempunyai nilai signifikansi 0,012, yang berarti nilai ini lebih kecil dari taraf signifikansi sebesar 0,05 seperti yang diharapkan peneliti, sehingga pengujian menunjukkan hasil bahwa hipotesis keenam diterima. Namun mempunyai nilai t hitung $-2,535$, yang berarti menunjukkan arah negatif. Dengan demikian variabel besaran dewan komisaris menunjukkan hubungan yang negatif memiliki pengaruh terhadap praktik perekayasaan laba. Hal ini menunjukkan bahwa semakin besar perusahaan maka semakin besar pula kesempatan manajer dalam melakukan perekayasaan laba.

Hasil penelitian ini konsisten dengan penelitian terdahulu yang menunjukkan hasil penelitian adanya korelasi negatif antara besaran korporasi terhadap perekayasaan laba (Muklis, 2016). Perusahaan besar memiliki aktivitas operasional yang lebih kompleks sehingga dapat dengan leluasa memberikan celah bagi pihak manajer untuk memanipulasi laba. Perusahaan besar yang memiliki investor besar tentunya turut memiliki target pencapaian laba yang besar sehingga mendorong pihak manajer untuk melakukan tindakan mempercantik (windows dressing) laporan keuangan.

\section{KESIMPULAN, KETERBATASAN, DAN SARAN}

\subsection{Kesimpulan}

Berdasarkan hasil pengujian terhadap hipotesis dan analisa data yang telah diuraikan sebelumnya, maka dapat diambil kesimpulan bahwa:

1. Investor institusi memiliki pengaruh positif terhadap praktik perekayasaan laba yang diukur dengan discretionary accruals. Semakin besar jumlah investor institusi maka semakin rendah motivasi manajemen untuk melakukan perekayasaan laba.

2. Managerial ownership memiliki pengaruh positif terhadap praktik perekayasaan laba yang diukur dengan discretionary accruals. Semakin rendah persentase managerial ownership maka semakin rendah motivasi manajemen untuk melakukan perekayasaan laba.

3. Komite audit memiliki pengaruh positif terhadap praktik perekayasaan laba yang diukur dengan discretionary accruals. Semakin sedikit jumlah komite audit maka semakin rendah motivasi manajemen untuk melakukan perekayasaan laba.

4. Persentase komisaris independen memiliki pengaruh negatif terhadap praktik perekayasaan laba yang diukur dengan discretionary accruals. Semakin tinggi persentase komisaris independen maka semakin rendah motivasi manajemen untuk melakukan perekayasaan laba.

5. Besaran dewan komisaris memiliki pengaruh negatif terhadap praktik perekayasaan laba yang diukur dengan discretionary accruals. Semakin besar jumlah komisaris maka semakin rendah motivasi manajemen untuk melakukan perekayasaan laba.

6. Besaran korporasi memiliki pengaruh negatif terhadap praktik perekayasaan laba yang diukur dengan discretionary accruals. Semakin kecil korporasi maka semakin tinggi motivasi manajemen untuk melakukan perekayasaan laba. 


\subsection{Keterbatasan}

Keterbatasan dalam penelitian ini adalah sebagai berikut:

1. Tahun yang digunakan dalam penelitian ini hanya dua tahun sehingga kurang mencerminkan kondisi jangka panjang obyek penelitian.

2. Variabel-variabel independen di atas masih belum mencakup atau mampu mengukur mekanisme tata kelola korporasi didalam perusahaan secara keseluruhan.

\subsection{Saran}

Dari keterbatasan-keterbatasan diatas maka saran yang dapat diberikan oleh peneliti adalah sebagai berikut:

1. Perusahaan yang menjadi populasi tidak diklasifikasi kondisi keuangannya. Perusahaan yang mengalami tekanan keuangan dan yang sehat tentu memiliki perbedaan motivasi dan kebijakan akuntansi yang dipilih. Penelitian mendatang dapat mengklasifikasi keadaan perusahaan untuk memastikan perbedaan motivasi perataan penghasilan.

2. Penelitian selanjutnya, sebaiknya menggunakan periode yang lebih lama agar pengaruh dari variabel independen terhadap variabel dependen lebih menggambarkan kondisi jangka panjang obyek penelitian. Untuk penelitian selanjutnya, peneliti disarankan untuk meneliti variabel lain diluar variabel penelitian ini yang mungkin dapat mempengaruhi praktik perekayasaan laba.

\section{DAFTAR PUSTAKA}

Al-Shetwi, M. 2011. Impact of dari dalam audit function (IAF) on financial reporting quality (FRQ): Evidence from Saudi Arabia. African Journal of Business Management 5 (27):11189-11198.

Aygun, M., S. Ic, dan M. Sayim. 2014. The Effects of Corporate Ownership Structure and Board Size on Earnings Management : Evidence from Turkey. International Journal of Business and Management 9 (12):123-132.

Azeem, M., M. Ul Hassan, dan R. Kouser. 2013. Impact of quality corporate governance on firm performance: A ten year perspective. Pakistan Journal of Commerce and Social Sciences (PJCSS) 7 (3):656-670.

Dar, L. A., M. A. Naseem, R. U. Rehman, dan D. G. S. K. Niazi. 2011. Corporate Governance and Firm Performance a Case Study of Pakistan Oil and Gas Companies Listed in Karachi Stock Exchange. Global Journal of Management and Business Research 11 (8):1-10.

Essa, S., R. Kabir, dan H. T. Nguyen. 2016. Does Corporate Governance Affect Earnings Management? Evidence from Vietnam. Department of Finance and Accounting:1-27.

Fudenberg, D., dan J. Tirole. 1995. A Theory of Income and Dividend Smoothing Based on Incumbency Rents. Journal of Political Economy 103 (1):75-93.

Hashim, H. A. 2012. The influence of culture on financial reporting quality in Malaysia. Asian Social Science 8 (13):192-199.

Kustono, A. S., dan R. Effendi. 2017. Earnings Management and Corporate Governance Case in Indonesia. Advanced Science Letters 22 (12):4345-4347.

Lestari, L. S., dan S. Pamudji. 2013. Pengaruh Earnings Management terhadap Nilai Perusahaan Dimoderasi dengan Praktik Corporate Governance (Studi 
Empiris pada Perusahaan Non Keuangan yang terdaftar di Bursa Efek Indonesia Tahun 2008-2011) 2:494-502.

Mansor, N., A. Che Ahmad, N. A. A. Zaluki, dan A. H. Osman. 2013. Corporate Governance and Earnings Management: A Study on the Malaysian Family and Non-family Owned PLCs. Procedia Economics and Finance 7 (Icebr):221229.

Moh Fadzilah, N. S. 2017. Board of directors' characteristics and earnings management of family owned companies. International Journal of Accounting \& Business Management 5 (2):68-83.

Muklis, F. 2016. Struktur kepemilikan, ukuran perusahaan dan leverage. . Al-Masraf: Jurnal Lembaga Keuangan Dan Perbankan 1 (2):245-255.

Omrani, A. A. 2016. Evaluating the modifying effect of corporate governance on the relationship between free cash flow and earnings management of companies listed in Tehran Stock Exchange. International Journal of Humanities and Cultural Studies Special Fe (1):104-118.

Rossi, P. R. 2014. Earnings Management in India. CFA Digest 44 (3 ).

Shaiks, A. M., M. J. Iqbal, dan S. Z. A. Shah. 2012. Institutional Ownership and Discretionary Accruals: Empirical Evidences from Pakistani Listed NonFinancial Companies. Information Management and Business Review 4 (4):217-222.

Spinos, E. 2013. Managerial Ownership and Earnings Management in Times of Financial Crisis : Evidence from the USA. Journal of Accounting and Business Education.

Susanto, Y. K. 2018. The Effect of Corporate Governance Mechanism on Earnngs Management Practice (Case Study on Indonesia Manufacturing Industry). Jurnal Bisnis dan Akuntansi 15 (2):157-167.

Titik, F., dan M. S. Putri. 2014. Pengaruh Kepemilikan Manajerial, Leverage Dan Ukuran Perusahaan Terhadap Manajemen Laba Pada Perusahaan Food And Beverage (Studi pada Perusahaan Food and Beverage yang Terdaftar di Bursa Efek Indonesia tahun 2008 - 2013). Jurnal Akuntansi \& Keuangan Universitas Telkom 1 (3):2-5.

Ustman, I. Subekti, dan A. Ghofar. 2016. Analisis Pengaruh Manajemen Laba Terhadap Nilai Perusahaan Sebelum Dan Saat Implementasi IFRS. Jurnal Ekonomi Dan Bisnis 10 (1):49-61.

Young, S. 2015. Earnings Management and Corporate Governance. Wiley Encyclopedia of Management 4 (3):1-5. 